\title{
THE STUDY ANALYSIS OF IRON DEFICIENCY ANEMIA FOR FEMALE STUDENTS OF STATE SENIOR HIGH SCHOOL
}

\author{
Putri Permatasari ${ }^{1}$, Anjang Priliantini ${ }^{2}$ and Sheila Rizkia Anjani ${ }^{3}$ \\ ${ }^{1,3}$ Department of Public Health, Faculty of Health Sciences, Universitas Pembangunan Nasional Veteran Jakarta, \\ Indonesia \\ ${ }^{2}$ Department of Communication, Faculty of Social Political Sciences, Universitas Sebelas Maret Surakarta, Indonesia
}

Corresponding author: Putri Permatasari

Email: putripermatasari@upnvj.ac.id

\begin{abstract}
Iron deficiency anemia in adolescents is one of the public health problems that has not been overcome especially in young women. One of the indirect causes are income, parental education, and low knowledge about anemia and balanced nutrition. Quantitative design with descriptive study supported with qualitative design. Samples were female students of State Senior High Senior $(n=394)$. Data were collected using questionnaire. Anemia prevalence was $46.4 \%$, with classifications on severe level at $8.6 \%$, moderate level at $20.1 \%$, and mild level at $17.8 \%$. Respondents' knowledge about anemia was pretty good (67.3\%), balanced nutrition (51.3\%). The observation showed that the foods in the cafeteria were not varied, unhealthy, not nutritious, and unhygienic. Personal hygiene and food sanitation were low. There were no regulations and no changing menu schedules. Peer group takes role on selecting foods. Balanced nutrition food had not been well-socialized. Knowledge of anemia, balanced nutrition, which is quite high, do not reduce the prevalence of anemia in adolescent. It is needed to take interventions to prevent and overcome iron deficiency anemia with holistic communication network among students, school authorities, and cafeteria management.
\end{abstract}

Keywords: Communication Network, Female Adolescents, Iron eficiency anemia

\section{INTRODUCTION}

Adolescent is one group that will obtain social roles and form the family in the future. Young women will prepare themselves to produce human resources with good quality, play a role in continuing development which determines the future of the nation. Therefore they must be physically, mentally, socially and spiritually healthy. Adolescence is a transition period between childhood and early adulthood, lasting between the ages of 10-19 years and is the fastest growth and development period after baby period (Wijaya, et al 2014). Growth and development of adolescents will be achieved well if supported by a healthy environment and balanced nutritional intake, both macro and micro nutrients. The lack of one of these nutrients will disrupt their growth and health such as anemia.

Iron deficiency anemia in adolescents is one of public health problems that until now has not been overcome especially in young women. The highest prevalence of anemia occurs in women and girls (Ministry of Health [MoH], 2014). In developed countries the prevalence of anemia is estimated at $9 \%, 43 \%$ in developing countries, and $30 \%$ in women of reproductive age (15-49 years) (McLean E, et al, 2009). Basic Health Research (Riset Kesehatan Dasar i.e. Riskesdas) year 2013 showed the incidence of anemia nationally is $21.7 \%, 18.4 \%$ in men and $23.9 \%$ in women $(\mathrm{MoH}$, 2014). World Health Organization (WHO) targets the prevalence of anemia in women of reproductive age decreased by 50\% in 2025 (WHO, 2014).

\section{Literature review \\ Anemia}

The cause of anemia is not only due to individual factors but is the result of interdependence between individual, family, and society, as well as the physical environment. Individual factors include menstruation, low knowledge of anemia and balanced nutrition, and the application of balanced nutrition messages. Family factors include education, employment and income of parents, and family eating patterns. Study showed that one of the factors that influence the incidence of anemia is the level of maternal education (Martini, 2015). Education levels, low socioeconomic, demographic, and unhealthy lifestyles are related to anemia (Permaesih and Herman, 2005).

The level of education is one factor that influence somebody's knowledge (Notoatmodjo, 2012). Study in Bengkulu City showed that the knowledge of adolescent girls about anemia was less than $44.75 \%$ and the prevalence of iron deficiency anemia was $43 \%$ (Suryani et al, 2015). The incidence of anemia in West Java was $51.7 \%(\mathrm{MoH}$, 2012). Anemia in young women was quite high, estimated at 36\% (Depok City News, Monday, October 17, 2016). Environmental factors, such as the availability of foods at the cafeteria, lunch brought from home, school policies regarding rules of the cafeteria, influence of friends and 
advertisements, are factors that contribute to the incidence of iron-deficiency anemia.

Consequences that arise when young women are anemic, in the short term, reduce endurance and concentration and learning achievement. The adolescent girls who experienced anemia had a risk of 1.875 times lower in learning achievement than those who were not anemic (Astiandani, 2015). Likewise, the study of Dumilah et al (2017) showed a significant relationship between learning achievement and anemia ( $p$-value 0.026). Long-term consequences of anemia in the next stage of life i.e. in pregnancy, are bleeding, miscarriage, low birth weight (LBW), premature and disability, as well as an increased risk of maternal and infant death (Saifuddin, 2014).

\section{Iron Deficiency Anemia}

One of the causes of iron deficiency anemia is lack of consuming iron-containing foods such as meat, fish, liver, tempeh, dark green vegetables, nuts and fruits (Merryana et al, 2012). Given the consequences of iron deficiency anemia in adolescents that are very serious, it is needed to know the anemia causes of individual, family and environmental aspects. Individual factors include the lack of consumption of iron sources, low knowledge of iron deficiency anemia, balanced nutrition, and the application of balanced nutrition messages. Family factors include the level of education, employment and income, and family eating habits. Environmental factors include school policies, available menus, opening and closing schedule of cafeterias, food hygiene and sanitation in the cafeteria, and peer groups.

\section{Prevention Programs}

Prevention programs of anemia has been widely carried out by Primary Health Care and other health services. The programs include running a nutritional supplementation program through the provision of food and nutritional products, giving iron tablets and vitamin A, food fortification i.e. iron fortification in flour, and nutritional education programs. However the prevalence of iron deficiency anemia is still high. To prevents the high risk of nutritional disorders in adolescents, such as iron-deficiency anemia, the government issued Regulation of the Minister of Health of the Republic of Indonesia No. 41 of 2014 concerning Balanced Nutrition Guidelines that specifically have messages for adolescents (ages 10-19 years) in order for healthy adolescents and avoid various diseases i.e. iron deficiency anemia.

\section{METHODS}

\section{Research design}

The study design used was descriptive quantitative research and supported by qualitative techniques through observation and interviews to verify things that are not explored through quantitative methods. In this study, observation is carried out with a focus on school cafeterias. There were three aspects observed, namely: (1) cafeteria management and physical environment as well as the type and price of food; (2) food hygiene and sanitation, and the knowledge of the cafeteria officer about the wellbalanced menu; (3) the behavior of the peer groups in choosing the menu and type of food. Determination of hemoglobin $(\mathrm{Hb})$ levels was carried out with peripheral blood tests, using the Quick Check Hb tool. The Body Mass Index (BMI) was calculated based on the calculation of body weight in kilograms divided by the square of the height in meters $\left(\mathrm{kg} / \mathrm{m}^{2}\right)$. Weight measurements were carried out with a 289 digital HN body scale, and height measurements were performed with microtoise.

\section{Samples and informants}

The sample consisted of grade $X$ and $X I$ female students of State Senior High School 6 Depok with a total of 394 people, with Class X students majoring in Natural Sciences and Social Sciences amount to 175 people and Class XI students majoring in Natural Sciences and Social Sciences amount to 219 people. There were six informants, namely the headmaster and five cafeteria officers. The inclusion criteria were students aged 15 to 17 years old, registered as active students, and willing to participate in the study by signing the Informed Consent form. The exclusion criteria were they who were not present or were not willing to check hemoglobin or were not willing to fill out the questionnaire.

\section{Data Processing and Analysis Data}

All data collected through questionnaires were edited, entered, cleaned and then, processed. Quantitative analysis was carried out with univariate, presented in the form of tables and narratives. Qualitative data was processed by reducing data from observations and in-depth interviews. The researchers selected and focused attention to simplify, to do abstraction, and to transform the data. Data were presented with descriptions of narrative forms.

\section{RESULTS}

\section{Description of Nutritional Status, Occurrence of} Anemia, Classification of Anemia

The study showed that the majority of respondents had normal nutritional status $(69.3 \%)$, the remaining were spread in malnutrition status. Nearly half $(46.4 \%)$ of the respondents were anemic, with the classification of severe anemia $8.6 \%$, moderate anemia $20.1 \%$, and mild anemia $17.8 \%$. 
Table 1: Distribution of Respondents according to Nutritional Status, HB Level, Classification of Anemia $(n=394)$

\begin{tabular}{lcc}
\hline Variables & $\mathbf{n}$ & $\%$ \\
\hline Nutritional status & & \\
Underweight (BMI < 17) & 20 & 5.1 \\
(BMI 17 - 18.4) & 266 & 67.0 \\
Normal (BMI 18.5 - 25) & 24 & 6.1 \\
Overweight (BMI > 25.1 - 27) & 29 & 7.4 \\
Obese (BMI > 27) & & \\
Hemoglobin level & 183 & 46.4 \\
Anemic (Hb < 12 gr\%) & 211 & 53.6 \\
Non-anemic (Hb $\geq 12$ gr\%) & & \\
Classification of Anemia & 34 & 8.6 \\
Severe & 79 & 20.1 \\
Moderate & 70 & 17.8 \\
Mild & & \\
\hline
\end{tabular}

Description of Knowledge of Iron Deficiency Anemia, Balanced Nutrition and Application of Balanced Nutrition Messages

The study showed that the average of respondents' knowledge about anemia and balanced nutrition was in sufficient and high category. There were no respondents with low level of knowledge. The highest percentage of anemia and balanced nutrition knowledge was in the sufficient category, the remaining was in the high category, but only $36 \%$ of respondents applied the balanced nutrition messages according to PGS.

Table 2: Distribution of Respondents according to Knowledge of Anemia, Balanced Nutrition and Application of Balanced Nutrition Messages $(n=394)$

\begin{tabular}{lcc}
\hline Variables & $\mathbf{n}$ & $\%$ \\
\hline Knowledge of anemia & 265 & 67.3 \\
Sufficient & 129 & 32.7 \\
High & & 51.3 \\
Knowledge of balanced nutrition & 202 & 48.7 \\
Sufficient & 192 & \\
High & 252 & 64.0 \\
Application of Balanced Nutrition Messages & 142 & 36.0 \\
Not in accordance with PGS & & \\
In accordance with PGS & & \\
\hline
\end{tabular}

Application of Special Messages for Balanced Nutrition for Youth (10-19 years)

The study showed that all respondents consumed rice as staple food. Only $39.8 \%$ of respondents consume rice three times a day, $52.8 \%$ of respondents often eat breakfast, $50.8 \%$ of respondents often consume animal side dishes, and only $26.1 \%$ of respondents consume more servings of vegetables and fruits. Only $21.3 \%$ of respondents often consume vegetables and fruits. Most respondents $(72.6 \%)$ often bring and drinking water from home. From the observations, it was known that lunch brought by students were processed foods such as chicken nugget, fried chicken, instant fried noodles, and fried sausages.

The study showed that $52.8 \%$ of respondents often consume fast food and junk food, only $16.5 \%$ of respondents often drink tea/coffee during meals or two hours after meals, $43.9 \%$ of respondents often read labels before buying packaged food, and $82.2 \%$ of respondents often hunger to stay slim. 
Table 3: Distribution of Respondents according to the Application of Balanced Nutrition Messages ( $n$ $=394)$

\begin{tabular}{lcccc}
\hline \multirow{2}{*}{ Application of Balanced Nutrition } & \multicolumn{2}{c}{ No/seldom } & \multicolumn{2}{c}{ Yes/often } \\
\cline { 2 - 5 } & $\mathrm{n}$ & $\%$ & $\mathrm{n}$ & $\%$ \\
\hline Consuming rice three times a day & 237 & 60.2 & 157 & 39.8 \\
Having breakfast before going to school & 186 & 47.2 & 208 & 52.8 \\
Consuming animal side dishes & 194 & 49.2 & 200 & 50.8 \\
Consuming more servings of vegetables and fruits & 291 & 73.9 & 103 & 26.1 \\
Consuming green vegetables and fruits & 310 & 78.7 & 84 & 21.3 \\
Bringing lunch and drinking water from home & 108 & 27.4 & 286 & 72.6 \\
Consuming fast food, sweet, salty and fatty food (fast & 186 & 47.2 & 208 & 52.8 \\
food and junk food) & & & & \\
Drinking tea/coffe during meals or two hours after & 329 & 83.5 & 65 & 16.5 \\
meals & 221 & 56.1 & 173 & 43.9 \\
Reading labels before buying packaged food & 70 & 17.8 & 324 & 82.2 \\
Stay hunger to stay slim & & & &
\end{tabular}

Data source : field research (2018)

\section{Observations as Supporting Techniques}

In this study, the observation is one of qualitative techniques for verification to explain things that have not been revealed through quantitative methods. In this study, observations focused on the school cafeteria, as a context for the availability of foods and drinks. There were three aspects observed: (1) management (2) food hygiene and sanitation and knowledge of cafeteria officers about balanced menu; (3) peer group behavior in choosing menus and types of food.

\section{Cafeteria management}

School cafeterias play an important role in food supply. Cafeteria officers need to have good knowledge about nutrition, balanced nutrition, and food sanitation and hygiene. School managers need to have rules regarding opening and closing schedule of cafeterias, rules for eating, and places to eat for students who bring lunch.

Management of school cafeterias at State Senior High School 6 Depok is carried out through school cooperative. The results of interviews with the headmaster showed that there were no rules for the opening and closing schedule of cafeterias, types of food, monthly menu arrangement, health requirements for staffs, food hygiene and sanitation. The results of interviews indicated that the management of the cafeteria did not have the opening and closing schedule and varied menu arrangement.

The school did not yet have the requirements for the cafeteria staffs. Staffs were determined entirely by cafeteria tenants who have been serving regularly without any complaints from the school administrators or students.

From the observations on the cafeteria and indepth interviews with the headmaster, it can be concluded that there are no rules about the opening and closing schedules of the cafeteria, menu variations provided by the cafeteria, food hygiene and food sanitation. If the rule is not compiled then malnutrition, such as micronutrient deficiencies in students, will increase. This can result acceptance disruption and low learning quality, adversely affects subsequent growth and development.

\section{Food Hygiene and Sanitation}

The cafeteria staffs did not use special clothes. According to the Decree of the Minister of Health of the Republic of Indonesia Number $1098 / \mathrm{MENKES} / \mathrm{SK} / \mathrm{VII} / 2003$, the cafeteria staff is a person who is directly related to foods and equipments from the preparation, cleaning, processing, transportation and serving. The requirements of the cafeteria staffs are be healthy, not suffering from infectious diseases such as typhus, cholera, and tuberculosis. Staffs who suffer from respiratory, digestive and skin diseases, should not be involved in food handling. It is better for cafeteria staffs to take health tests, especially blood tests and $\mathrm{x}$-rays, which are repeated every six months, especially for the chefs.

The observations showed that all cafeteria staffs did not use aprons, headgear, or masks, taking food using tools such as spoons or food tongs, but hands still touching food. None of the cafeteria staffs used gloves when taking food and washed their hands before and after serving food.

The observations also showed that the type of foods available at the cafeteria did not meet the needs of students. Most of the cafeteria staffs process food at home, so that in the cafeteria they only heats it up. This way was done by drink sellers (sweet tea, fruit ice, green tea, cappuccino) and 'batagor', 'siomay' and snacks sellers. 
The knowledge of the Cafeteria Staffs about the Balanced Menu

From the types of foods provided in the cafeteria, it is known that the staffs do not pay attention to the sources of nutrients in foods, such as sources of protein, vitamins and minerals, and sources of iron. There is no menu change schedule.

The menu arrangement that was provided in the cafeteria did not change since the cafeteria was opened in 2004 until this research was carried out. So it can be concluded that the food menu at the cafeteria does not vary, so it does not fulfill balanced nutrition food. The research team continued the interview, asking about the balanced menu. The cafeteria staffs replied "not yet, we only know Healthy Four Perfect Five". But, there was a cafeteria staff said:

From the observations on the cafeteria and indepth interviews with cafeteria staffs, it can be concluded that knowledge of balanced nutrition has not been well socialized among cafeteria staffs. This problem can increase malnutrition and micronutrient deficiencies in students, because the foods consumed is very important in improving student health and growth. Therefore, the school cafeteria needs to provide the type of food in accordance with the balanced nutrition message so that they can meet the needs of students to grow and be healthy. This study showed that $46.4 \%$ of students experienced iron deficiency anemia. Only $67.5 \%$ of students had normal nutritional status, the remaining experienced underweight and overweight.

\section{Student Peer Group}

From the observations, it is known that respondents generally are grouped according to their friendship, consisting of two to five people. Interaction between friends is quite close, seen during recess, they go to the cafeteria together while chatting and asking each other about the choices of food. Eventually, they order one type of food but in different taste. They sit together, eating together, telling each other, about lessons, homework, and so on. Groups that do not get a seat, purchase and bring snacks they bought to the class and then eat snacks together. Respondents who bring lunch share and taste each other. The types of lunch are processed fried chicken or chicken nuggets. This grouping is one of the characteristics of adolescent development. Peer group is very important and influence each other in their lives, as a place they confide, play, discuss and carry out the same activities.

\section{DISCUSSION}

\section{Characteristics of respondents}

This study showed that the majority of respondents aged 16-17 years. This age is the middle age of adolescence (Minister of Health Regulation No. 25 of 2014). At this period, there is rapid growth, physically, psychologically and intellectually. Half of the respondents (66.5\%) have pocket money $\geq$ Rp20.000,00. Pocket money is money that is brought for necessity at any time (Ministry of National Education, 2008: 1513). During the interviews, several respondents said that their pocket money is used to buy food. Food is a source of energy that the body needs to live, learn, and concentrate. The amount of pocket money is enough to buy food in the cafeteria, such as meatballs, mixed rice, 'cilok', 'cireng' and other snacks.

Most of the respondents' extracurricular activities are physical activities that require high calories, i.e. PMR, volleyball, futsal and karate. Extracurricular activities are additional activities outside of school hours, useful for developing selfpotential, adding friend experiences, and skills (Hapsari, 2010). These activities require additional energy expenditure, if it is not fulfilled then occur malnutrition. The study showed that $19.1 \%$ respondents experienced severe and mild malnutrition. Therefore extracurricular activities must be balanced with a balanced nutrition supply.

\section{Characteristics of parents}

The level of education influences one's knowledge, thoughts, insights, which is reflected in behavior (Notoatmodjo, 2012). The higher the level of education, the wider the knowledge. Most of the respondents' parents had a high level of education, so that it is easy to follow the development of modernization and receive information. The level of education correlates with parental work and income. Most of the respondent's fathers work as private employees whose income is more than Depok City Minimun Wage $($ Rp3.584.700,29). The high income of parents is reflected in the availability of foods at home for lunch brought by students. The study showed that lunch brought from home consist of processed foods such as fried chicken, nuggets, instant noodles and french fries. The availability of foods at home depends on the amount of funds available for the purchase of family food (Notoatmodjo, 2012).

\section{Nutritional Status and Anemia Status of Respondents}

Nutritional status is a state of the body that is affected by certain nutrients as a result of food consumption. The important factors that determine nutritional conditions, i.e. nutritional intake, physical activities, and infectious diseases. The study showed that only $69.3 \%$ of respondents had normal nutritional status and the remaining were underweight and overweight. This increases risk for the occurrence of degenerative diseases such as hypertension, diabetes mellitus, coronary heart disease and also developing growth disorders, especially to the reproductive system (Supariasa et al, 2014).

Nearly half $(46.4 \%)$ of respondents were anemic, $8.6 \%$ of them experienced severe anemia, $20.0 \%$ of 
them experienced moderate anemia, and $17.8 \%$ of them experienced mild anemia. Anemia in adolescents can reduce physical abilities and academic performance. Anemia causes blood to be insufficiently binding and transports oxygen from the lungs to the rest of the body, especially to the brain. Therefore anemic students experience dizziness, dizzy eyes, fatigue, and sleepy. These things result in difficulty concentrating, low physical endurance, decreased physical activity, easily infected with diseases, and decreased learning achievement. In the short term anemia can lead to delays in physical growth and sexual maturity (Helen, 2006). Long-term impacts of anemia are at high risk during pregnancy and childbirth, such as a miscarriage, bleeding, and even death. Besides, infants will be at risk of birth defects and low birth weight (Regulation of the Minister of Health, 2014).

\section{Knowledge of iron nutrition anemia, balanced nutrition and application of balanced nutrition messages}

The study showed that all respondents had sufficient and high knowledge about iron deficiency anemia and balanced nutrition. The knowledge is not only obtained through school education but also through non-formal education, mass media, other people, magazines, television, radio, and video via the internet, and others. This added to their insight, so their knowledge of anemia and balanced nutrition is quite good. However, the knowledge is not implemented in actions. It can be seen from the results of the study that only $36 \%$ of respondents applied balanced nutrition messages.

The Global School Health Survey in 2015 showed that $65.2 \%$ of teenagers do not always have breakfast (Ministry of Health, 2018). While the rate in this study is lower, only $47.2 \%$. This situation, for a long time, can interfere concentration and can lead to decreased performance, as well as the risk of interference with the digestive system. Likewise, the study showed that only $50.8 \%$ respondents often consumed animal side dishes. Animal side dishes are a source of protein needed for growth, building cells and tissues, and maintaining the immune system, as well as sources of iron (Almatsier, 2001). This can have an effect on physical disturbances, impaired growth, and iron nutritional anemia.

The study showed that most of respondents (78.2\%) did not consume vegetables and fruits. This result was supported by the Riskesdas in 2013. It is stated that $96.4 \%$ of the population aged 10 years and over consumed less fruits and vegetables in West Java Province. This condition needs to be noticed by various parties, especially schools and families and the places that teenagers like to gather.
The study showed that more than half of respondents $(52.8 \%)$ often consumed fast food and junk food. Fast Food and junk food are favorite foods and trends for teenagers, as well as respondents in this study. Junk food and fast food do not have complete nutritional content. Based on observations and interviews, students brought lunch in the form of processed foods (instant noodle, nuggets, kentucky fried chicken). This condition proved that respondents have not implemented balanced nutrition messages. The results of the observation showed that the composition of the menu in the cafeteria and the lunch brought from home did not describe the application of balanced nutrition messages. The most available source of nutrients in the cafeteria is the source of energy, while the protein as a form of hemoglobin is very lacking and so is the lunch. Processed foods are low in nutrients, high in fat and calories which can lead to anemia.

\section{CONCLUSION}

The prevalence of iron-deficiency anemia among female students in State Senior High School 6 Depok is still high with the most classification of moderate nutritional anemia. More than a third of the respondents experienced malnutrition (overweight and obese, very thin and thin). Most of the students' had sufficient and high knowledge about anemia and balanced nutrition while the application of balanced nutrition messages is not in accordance with the message of balanced nutrition for adolescents. The physical environment of cafeteria, hygiene and food sanitation has not met the requirements of a healthy cafeteria. School managers do not have rules regarding the requirements of cafeteria staffs and the management of a healthy cafeteria. Therefore the menu arrangement does not vary and has not fulfilled balanced nutrition. The knowledge of the cafeteria staffs about balanced nutrition is still low. The balanced menu arrangement has not been well socialized.

Intervention action is needed to implement school policies through prevention and mitigation programs related to anemia through a holistic communication network between students, schools, and cafeteria management.

\section{Conflict of interest}

The authors declare no potential conflict of interest.

\section{REFERENCES}

1. Departemen Pendidikan Nasional. 2008. Pengertian Uang Saku (http//wordpress.com.) Diakses tanggal 14 Januari 2017.

2. Helen, V. 2006. Buku Ajar Asuhan Kebidanan. Jakarta; hlm. 126-127. 
3. Kementerian Kesehatan RI. 2018. Global School Health Survey tahun 2015 "Pola makan remaja" Biro Komunikasi dan Pelayanan Masyarakat.

4. Kementerian Kesehatan Republik Indonesia. 2014. Pedoman Gizi Seimbang. Jakarta. Kemenkes RI

5. McLean E, Cogswell M, Egli I, Wojdyla D, de Benoist $B$. Worldwide prevalence of anaemia, WHO Vitamin and Mineral Nutrition Information System, 1993-2005. Public Health Nutr 2009; 12: 444-54

6. Martini, M. 2015. Faktor-Faktor yang Berhubungan dengan Kejadian Anemia pada Remaja Putri di MAN 1 Metro. Jurnal Kesehatan Metro SaiWawai, 8(1), p 1-7.

7. Notoatmodjo, S. 2012. Promosi Kesehatan dan Perilaku Kesehatan. Jakarta: Rineka Cipta.

8. Permaesih, D dan Herman, S. 2005. Faktor-Faktor yang Mempengaruhi Anemia pada Remaja. Buletin Penelitian Kesehatan, Vol.33, No.4: 162-171

9. Peraturan Menteri Kesehatan Republik Indonesia No. 41 tahun 2014 tentang Pedoman Gizi Seimbang; Menteri kesehatan Indonesia.

10. Hapsari. 2010. Hubungan Antara Minat Mengikuti Kegiatan Ekstrakurikuler dengan Intensi Delinkuensi Remaja pada Siswa Sekolah Menengah Kejuruan (Smk) Di Kota Semarang. (Jurnal). Universitas Diponegoro. Semarang.

11. Saifuddin AB. 2014. Ilmu Kebidanan. Jakarta; Bina Pustaka Sarwono Prawihardjo.

12. Suryani, Hafiani, Junita. 2015. Pola Makan dan Anemia Gizi Besi. Jurnal Kesehatan Masyarakat Andalas. Oktober 2015 Maret 2016 | Vol. 10, No. 1, Hal. 11-18.

13. Supariasa ID, Bakri B, Fajar I. Penilaian Status Gizi. Cetakan 2014. Jakarta: EGC. 2014. 1-324

14. World Health Organization. 2003. Fruit and Vegetable Promotion Initiative Report of The Meeting. Geneva (US): WHO.

15. Wijaya Kusuma dkk, 2014. Pengetahuan, sikap dan aktifitas remaja SMA Dalam Kesehatan reproduksi Di Kecamatan Buleleng. Jurnal Kesehatan Mayarakat 10 (1), (2014) : 33

16. World Health Organization. 2014. WHO Global Nutrition Targets 2025: Anaemia Policy

17. Brief. Geneva: World Health Organization. 2014. 